\title{
Mucormycosis: Association with Deferoxamine Therapy
}

Annemarie L. Daly, M.D., Luis A. Velazquez, M.D., Suzanne F. Bradley, M.D., CAROl A. Kauffman, M.D.

Ann Arbor, Michigan

M ucormycosis is an uncommon acute and often fatal opportunistic fungal infection that usually occurs in patients with poorly controlled diabetes mellitus, acute leukemias, or other immunosuppressive conditions $[1,2]$. A new association, that of mucormycosis occurring in patients receiving deferoxamine therapy for iron or aluminum excess, has been reported with increasing frequency since 1986 [3-16]. Although this association has been strongly linked with chronic renal failure requiring hemodialysis, it is now clear that other conditions in which deferoxamine may be required (thalassemia, sideroblastic anemia, myelodysplasia) are also associated with mucormycosis $[5,7,8,16]$. We report a case of mucormycosis in a patient who had received deferoxamine for iron overload secondary to myelodysplastic syndrome, and review previous cases of deferoxamine-associated mucormycosis.

\section{CASE REPORT}

A 56-year-old woman with myelodysplastic syndrome for six years and transfusion-related iron overload had received treatment with deferoxamine, 1 to $1.5 \mathrm{~g}$ per week, for seven months. She did well until June 1988, when she developed fever and a nonproductive cough. She was admitted to another hospital where she was treated with tobramycin, ticarcillinclavulanic acid, and erythromycin for presumed pneumonia. Over the course of the first hospital day, she remained febrile to $40.0^{\circ} \mathrm{C}$ and became somnolent and disoriented. The next day she was transferred to the University of Michigan Medical Center.

Upon arrival, her temperature was $40.1^{\circ} \mathrm{C}$, pulse 100 beats/minute, and blood pressure $140 / 78 \mathrm{~mm} \mathrm{Hg}$. She was lethargic, but arousable, and oriented to place and person. Although she had a right gaze preference, her eyes were able to cross the midline. A dense left visual field deficit was present; no papilledema was present. Oropharyngeal examination revealed only multiple palatal petechiae. Auscultation of the lungs detected scattered rhonchi. Her abdomen was soft and diffusely tender, and the splenic tip was palpable. Deep tendon reflexes were normal with bilateral flexor plantar responses.

Results of laboratory tests showed a white blood cell count of $16,000 / \mu \mathrm{L}$ with six neutrophils, eight band forms, 25 lymphocytes, 58 monocytes, one eosinophil, one basophil, and one metamyelocyte; hematocrit of $24 \%$; and platelet count of $82,000 / \mu \mathrm{L}$. Serum glucose was $102 \mathrm{mg} / \mathrm{dL}$, creatinine was $1.2 \mathrm{mg} / \mathrm{dL}$, and electro-

From the Division of infectious Diseases, Department of Internal Medicine, Veterans Administration Medical Center, University of Michigan Medical School, Ann Arbor, Michigan. Requests for reprints should be addressed to Carol A. Kauffman, M.D., Veterans Administration Medical Center, 2215 Fuller Road, Ann Arbor, Michigan 48105. Manuscript submitted February 13. 1989, and accepted April 4, 1989. lyte levels were normal. The chest roentgenogram showed a $6-\mathrm{cm}$ left perihilar mass. Head computed tomographic scan revealed a $3 \times 4$-cm non-enhancing low-attenuation right posterior parietal lesion that obliterated several sulci. She was treated with imipenem-cilastatin, acyclovir, and dexamethasone.

Over the next 18 hours, the patient showed neurologic deterioration with meningismus and bilateral extensor plantar responses. On the third day of hospitalization, amphotericin B was added to the treatment regimen. Bronchoscopy revealed a few yeast and Gram-positive diplococci in the washings; no organisms were found in specimens obtained by transbronchial lung biopsy. Her neurologic condition worsened with decreased responsiveness and left hemiplegia. The patient underwent intubation and ventilation and she was given mannitol. However, the right pupil became fixed and dilated, she remained febrile to $39.4^{\circ} \mathrm{C}$, and she died the next day.

Necropsy revealed central nervous system and pulmonary mucormycosis. Cerebral edema and a right parieto-occipital infarct were present. Microscopically, extensive infiltration of the right cerebral hemisphere and cerebral vessels by large non-septate hyphae was visible. The left pulmonary artery was occluded by a friable mass that invaded the wall, and the adjacent lung showed a large wedge-shaped hemorrhagic infarct. Microscopically, the mass in the pulmonary artery was composed of hyphae, multiple pulmonary vessels contained fungal emboli, and the lung was extensively infiltrated with fungi showing broad non-septate hyphae. Cultures of all fungal masses yielded Rhizopus species.

\section{RESULTS}

Although the first dialysis patient with mucormycosis, reported by Gluskin et al [17], was not noted to be receiving deferoxamine, subsequent cases of mucormycosis in patients undergoing dialysis have been in those receiving deferoxamine for aluminum or iron excess $[6-13,15]$. In addition to patients with renal failure, patients with hematologic disorders, all of whom were treated with deferoxamine, have been reported with mucormycosis $[3-5,14,16]$. Including the current one, we have found 26 cases of mucormycosis associated with states of iron or aluminum excess treated with deferoxamine (Table I).

Of the cases described in detail, 19 men and seven women were affected. The mean age was 49.6 years, with a range from 28 to 70 years. Of those cases in which the organism was identified, Rhizopus species occurred in $13[6,10,11,15,16]$ and Cunninghamella bertholletiae in three $[4,5,14]$.

Chronic renal disease requiring maintenance hemodialysis was present in 20 of the 26 patients $(77 \%)$ [6$13,15]$, whereas the remaining six patients had hema- 
TABLE I

Mucormycosis in Patients Receiving Deferoxamine for Iron or Aluminum Excess

\begin{tabular}{|c|c|c|c|c|c|c|c|c|}
\hline \multirow[b]{2}{*}{ Reference } & \multirow[b]{2}{*}{ Age/Sex } & \multirow[b]{2}{*}{$\begin{array}{l}\text { Underlying } \\
\text { Conditions }\end{array}$} & \multicolumn{3}{|c|}{ Deferoxamine Therapy } & \multirow[b]{2}{*}{ Organism } & \multirow[b]{2}{*}{$\begin{array}{c}\text { Organs } \\
\text { Involved }\end{array}$} & \multirow[b]{2}{*}{$\begin{array}{c}\text { Treatment/ } \\
\text { Outcome }\end{array}$} \\
\hline & & & $\begin{array}{c}\text { Dose } \\
\text { (g/week) }\end{array}$ & $\begin{array}{l}\text { Duration } \\
\text { (months) }\end{array}$ & Reason & & & \\
\hline [3] & $65 / M$ & $\begin{array}{l}\text { Sideroblastic } \\
\text { anemia }\end{array}$ & NS & 4 & $\mathrm{Fe}$ & NS & $\begin{array}{l}\text { Heart, lung, } \\
\text { brain, kidney, } \\
\text { spleen, liver, } \\
\text { adrenal }\end{array}$ & None/died \\
\hline [4] & $70 / M$ & $\begin{array}{l}\text { Thalassemia, } \\
\text { sideroblastic } \\
\text { anemia, diabetes }\end{array}$ & NS & NS & $\mathrm{Fe}$ & $\begin{array}{l}\text { Cunning. } \\
\text { hamella }\end{array}$ & Rhinocerebral & $\begin{array}{l}\text { Surgery/died } \\
\text { AmB }\end{array}$ \\
\hline [5] & $42 / M$ & $\begin{array}{l}\text { Thalassemia, } \\
\text { splenectomy, } \\
\text { chemotherapy }\end{array}$ & NS & NS & $\mathrm{Fe}$ & $\begin{array}{l}\text { Cunning- } \\
\text { hamella }\end{array}$ & $\begin{array}{l}\text { Skin, muscle, } \\
\text { nodes }\end{array}$ & AmB/lived \\
\hline [6] & $32 / M$ & Dialysis & 7 & 0.6 & $\mathrm{Al}$ & Rhizopus & $\begin{array}{l}\text { Heart, lung, } \\
\text { brain }\end{array}$ & None/died \\
\hline [7] & $32 / M$ & $\begin{array}{l}\text { Dialysis, } \\
\text { splenectomy }\end{array}$ & $2.5-6$ & 18 & $\mathrm{Al} / \mathrm{Fe}$ & NS & $\begin{array}{l}\text { Heart, lung, } \\
\text { brain }\end{array}$ & None/died \\
\hline [8] & $\begin{array}{l}45 / M \\
57 / M\end{array}$ & $\begin{array}{l}\text { Dialysis } \\
\text { Dialysis }\end{array}$ & $\begin{array}{l}2-6 \\
4-6\end{array}$ & $\begin{array}{r}4 \\
10\end{array}$ & $\mathrm{Al}$ & NS & Lung, bowel & $\begin{array}{l}\text { None/died } \\
\text { Surgerv/lived }\end{array}$ \\
\hline [9] & NS/M & Dialysis & $2-4$ & 4 & Al & NS & Rhinocerebral & $\begin{array}{l}\text { surgery/ived } \\
\text { None/died }\end{array}$ \\
\hline & NS/M & Dialysis & $2-4$ & 12 & Al & NS & Rhinocerebral & None/died \\
\hline \multirow[t]{4}{*}[10]{} & $47 / F$ & $\begin{array}{l}\text { Dialysis, } \\
\text { splenectomy }\end{array}$ & 4 & 12 & $\mathrm{Al} / \mathrm{Fe}$ & Rhizopus & $\begin{array}{l}\text { Brain, heart, } \\
\text { lung }\end{array}$ & None/died \\
\hline & $36 / F$ & Dialysis & 4 & 6 & Al & Rhizopus & $\begin{array}{l}\text { Brain, thyroid, } \\
\text { adrenal, heart }\end{array}$ & None/died \\
\hline & $60 / M$ & Dialysis & 3 & 12 & Al & Rhizopus & Skin & $\begin{array}{l}\text { Surgery/died } \\
\text { AmB }\end{array}$ \\
\hline & $45 / M$ & Dialysis & 3 & 18 & Al & Rhizopus & Rhinocerebral & $\begin{array}{l}\text { Surgery/sur- } \\
\text { AmB vived }\end{array}$ \\
\hline [11] & $\begin{array}{l}70 / M \\
68 / F \\
36 / M\end{array}$ & $\begin{array}{l}\text { Dialysis } \\
\text { Dialysis } \\
\text { Dialysis }\end{array}$ & $\begin{array}{c}6 \\
1.5 \\
4\end{array}$ & $\begin{array}{r}1 \\
12 \\
3\end{array}$ & $\begin{array}{l}\text { Al } \\
\text { Al } \\
\text { Al }\end{array}$ & $\begin{array}{l}\text { Rhizopus } \\
\text { Rhizopus } \\
\text { Rhizopus }\end{array}$ & $\begin{array}{l}\text { Lung } \\
\text { Brain } \\
\text { Heart, brain, } \\
\text { lung, stomach, } \\
\text { bowel, liver }\end{array}$ & $\begin{array}{l}\text { None/died } \\
\text { None/died } \\
\text { None/died }\end{array}$ \\
\hline $\begin{array}{l}{[12]} \\
{[13]} \\
{[14]}\end{array}$ & $\begin{array}{l}42 / \mathrm{M} \\
49 / \mathrm{M} \\
28 / \mathrm{F} \\
49 / \mathrm{M} \\
48 / \mathrm{F}\end{array}$ & $\begin{array}{l}\text { Dialysis } \\
\text { Dialysis } \\
\text { Dialysis } \\
\text { Dialysis } \\
\text { Myelodysplasia, } \\
\text { splenectomy }\end{array}$ & $\begin{array}{r}6 \\
6 \\
2 \\
6 \\
14\end{array}$ & $\begin{array}{r}2.5 \\
9 \\
5 \\
9 \\
18\end{array}$ & $\begin{array}{c}\mathrm{Al} \\
\mathrm{Fe} \\
\mathrm{Al} / \mathrm{Fe} \\
\mathrm{Fe} \\
\mathrm{Fe}\end{array}$ & $\begin{array}{c}\text { Rhizopus } \\
\text { Rhizopus } \\
\text { NS } \\
\text { NS } \\
\text { Cunning- } \\
\text { hamella }\end{array}$ & $\begin{array}{l}\text { Rhinocerebral } \\
\text { Rhinocerebral } \\
\text { Skin, brain } \\
\text { Rhinocerebral } \\
\text { Lung }\end{array}$ & $\begin{array}{l}\text { None/died } \\
\text { None/died } \\
\text { None/died } \\
\text { Surgery/died } \\
\text { Surgery/died } \\
\text { AmB }\end{array}$ \\
\hline \multirow[t]{3}{*}{ [15] } & $42 / M$ & Dialysis & 2 & 4 & Al & NS & $\begin{array}{l}\text { Heart, lung, } \\
\text { spleen, brain, } \\
\text { thyroid }\end{array}$ & None/died \\
\hline & $55 / M$ & $\begin{array}{l}\text { Dialysis, } \\
\text { glucocorticoids }\end{array}$ & 2 & 17 & Al & Rhizopus & $\begin{array}{l}\text { Lung, brain, } \\
\text { skin }\end{array}$ & None/died \\
\hline & $49 / F$ & Dialysis & $2-4$ & 16 & Al & NS & $\begin{array}{l}\text { Lung, liver, } \\
\text { spleen, heart }\end{array}$ & None/died \\
\hline [16] & $68 / M$ & Myelofibrosis & 10.5 & 20 & $\mathrm{Fe}$ & Rhizopus & $\begin{array}{l}\text { Lung, skin, } \\
\text { brain }\end{array}$ & AmB/died \\
\hline $\begin{array}{l}\text { Current } \\
\text { case }\end{array}$ & $56 / F$ & Myelodysplasia & $1-1.5$ & 7 & $\mathrm{Fe}$ & Rhizopus & Brain, lung & AmB/died \\
\hline
\end{tabular}

NS $=$ not stated; $\mathrm{Fe}=$ iron overload; $\mathrm{Al}=$ aluminum overload; $\mathrm{AmB}=$ amphotericin $\mathrm{B}$.

tologic disorders requiring frequent transfusions [3$5,14,16]$. Four patients, two with renal failure and two with hematologic disorders, had undergone splenectomy previously $[5,7,10,14]$. Only one patient each had diabetes mellitus [4], corticosteroid therapy [15], or chemotherapy [5].

The indications for deferoxamine therapy were iron overload (nine patients) [3-5,8,11,13,14,16,current case], aluminum overload (14 patients) $[6,8-11,15]$, and both iron and aluminum excess (three patients) $[7,10,12]$. All patients with aluminum excess were undergoing hemodialysis. The mean duration of deferoxamine therapy was 9.3 months, with a range from 19 days to 20 months. The dose of deferoxamine ranged from 1 to $14 \mathrm{~g}$ per week.

The clinical course noted in the patients in this series did not differ from that noted in patients with other risk factors for mucormycosis. Fourteen patients
(54\%) had disseminated infection $[3,5-8,10$ $12,15,16$,current case]; pulmonary and brain involvement was most prominent in these patients. Seven patients $(27 \%)$ had rhinocerebral disease $[4,9,10,11,13]$, two had pulmonary infection $[10,14]$, and one each had only cerebral, small bowel, or skin involvement, although it is likely that the latter patient had disseminated infection $[8,10,11]$. Presentation was acute in all but one patient, who presented with subacute infection of lymph nodes and subcutaneous tissue [5].

The clinical course was commented upon in 19 cases (four with rhinocerebral infection, 12 with disseminated infection, and three with localized disease). In patients with rhinocerebral infection, the mean duration of illness until death was only five days, and in those with disseminated infection, only six days. Rhinocerebral infection presented as facial pain or rhinorrhea; 
blindness occurred in three of four patients, and all four had increasing confusion and coma prior to death. Disseminated infection presented as necrotic cutaneous lesions in two patients $[12,16]$ and as pneumonitis (cough, fever, and pulmonary infiltrates) in seven patients $[3,6,7,15$, current case].

Only nine patients received any treatment that might have been helpful against mucormycosis. Three patients received amphotericin $B$ alone: our patient, Sanes' [16] patient, who received only one day of amphotericin B therapy prior to death, and Sand's [5] patient, who had subacute infection and was cured with $2 \mathrm{~g}$ of amphotericin B. Two patients had surgery alone-one had debridement of infected sinuses, which did not establish a diagnosis prior to death [13], and one had localized intestinal mucormycosis that was cured by surgical extirpation of the involved small bowel [8]. Four patients underwent surgical debridement of infected tissue and received treatment with amphotericin $B[4,10,14]$. In three instances, less than a week of therapy with amphotericin B was given prior to death.

In 19 of 26 cases (73\%), the diagnosis was not made until necropsy. Twenty-three of the 26 patients $(88 \%)$ died of mucormycosis. Three patients survived with the following: localized disease of the bowel cured by surgical extirpation [8], a subacute course involving skin, subcutaneous tissue, and nodes, which responded to amphotericin B therapy [5], and rhinocerebral infection treated with both surgical debridement and $1.5 \mathrm{~g}$ of amphotericin B [10].

Necropsy reports uniformly described tissue invasion with broad non-septate hyphae. Invasion through blood vessel walls with multiple infarcts and multiple abscesses was a common finding.

\section{COMMENTS}

Mucormycosis is an opportunistic mycotic infection caused by organisms belonging to the order Mucorales and the class Zygomycetes. The organisms most commonly implicated in clinical disease belong to the genera Mucor, Rhizopus, Absidia, and Cunninghamella [18]. Although wound infections with these organisms may occur in healthy individuals [19], invasive infection almost always occurs in patients with underlying diseases, especially acute leukemias and poorly controlled diabetes mellitus $[1,2]$. Rhinocerebral and pulmonary forms of the disease are the most common presentations of invasive infection, but widespread dissemination may also occur $[1,2]$.

Neutrophils and monocytes/macrophages are essential host defenses against the zygomycetes [20-23]. Patients with acute leukemia are at risk for developing mucormycosis primarily because of neutropenia [24]. However, patients with diabetes have normal numbers of neutrophils and generally normal phagocytic function [25]. Thus, another factor predisposing the diabetic patient to mucormycosis must be sought, and that factor may be ketoacidosis. Clinically, mucormycosis rarely occurs in diabetic patients unless they are experiencing ketoacidosis [20]. It has been shown in humans that ketoacidosis decreases neutrophil chemotaxis [26] and that in experimental alloxan-induced diabetes, ketoacidosis, and not hyperglycemia, is associated with invasive mucormycosis [27]. Not only is chemotaxis sluggish in ketoacidosis, but recent data show that serum inhibitory activity, which is normally present against the zygomycetes, is abolished in the course of ketoacidosis [28]. Thus, ketoacidotic serum will allow the growth of Rhizopus, but normal serum will not, unless the pH is lowered [28].

It is possible that acidosis is the essential factor leading to mucormycosis in patients undergoing dialysis. However, this seems unlikely since most patients have well-compensated acid-base balance, acidosis has not been noted specifically in those dialysis patients reported with mucormycosis, and furthermore, this factor would not explain the recent dramatic increase in mucormycosis seen in patients undergoing dialysis.

The increasing incidence of mucormycosis among patients undergoing dialysis and patients with chronic hematologic diseases can best be explained by the fact that all of these patients have been receiving the chelating agent, deferoxamine, which may alter the balance between iron metabolism of the host and iron requirements of the fungus. Many microorganisms require iron to grow, and conditions of iron excess have been known to predispose to infection with certain bacteria $[29,30]$. In fact, recent reports have emphasized that transfusion-related iron overload in patients undergoing dialysis predisposes these patients to bacteremia with Yersinia and Listeria $[31,32]$.

It is ironic that treatment with an agent that binds iron, such as deferoxamine, should be associated with an increased risk of infection with an iron-requiring organism such as Rhizopus. One would think that a chelator should decrease the risk of infection, and, in fact, that suggestion has been made [28]. The paradox of increased infection during chelation therapy can be explained by elucidation of how pathogenic microorganisms acquire iron from their host.

In human plasma or on mucosal surfaces, the amount of free iron available for microbial growth is very low; almost all of the iron is bound to proteins, such as transferrin and lactoferrin, or is locked in tissue stores. Microorganisms have evolved complex mechanisms to compete for iron in the host, usually by secreting siderophores, which trap iron and deliver it to the microorganism, thus enhancing growth. One of these siderophores is desferrioxamine B mesylate (deferoxamine) produced by Streptomyces pilosus. Thus, deferoxamine therapy provides benefit not only to humans receiving it for iron excess, but also to certain microorganisms, which do not produce their own siderophores but have the ability to utilize siderophores from other organisms [33]. The use of deferoxamine by bacteria to capture iron and increase virulence has been noted for both Yersinia enterocolitica and Vibrio vulnificus $[34,35]$. Clinically, yersinia bacteremia has been noted in patients undergoing dialysis who have received deferoxamine, but it is unclear whether the excess iron, use of the chelator, or both factors increased the risk for this infection $[32,36,37]$.

It is likely that the zygomycetes Rhizopus and Cunninghamella were able to utilize iron mobilized by deferoxamine to proliferate and cause invasive infection. These zygomycetes have been shown to produce only minimal amounts of siderophores and then only at room temperature after weeks in culture $[38,39]$. The fact that many of these patients were treated for aluminum excess and did not have iron overload implicates deferoxamine even more strongly.

The dismal rate of premortem diagnosis in the pa- 
tients reviewed contrasts sharply with the improved rate of diagnosis noted in recent years by Parfrey [2] and by Marchevsky et al [1]. This lack of early diagnosis in the patients presented in this review probably reflects the fact that the association of mucormycosis with either aluminum or iron overload treated with deferoxamine has only very recently been noted. Certainly, it is common knowledge that sinusitis, proptosis, or palatal lesions in a patient with poorly controlled diabetes mellitus or a hematologic malignancy should immediately suggest rhinocerebral mucormycosis. Similarly, a new infarct-like pulmonary infiltrate or necrotic skin lesions in such a patient also suggest mucormycosis. It is clear from the 26 patients reported in the last seven years that the aforementioned constellation of symptoms and signs in a patient receiving deferoxamine for iron or aluminum excess should also immediately raise the possibility of mucormycosis.

The diagnosis of mucormycosis is best made by biopsy and histopathologic examination of involved tissues. Microscopy will reveal broad, irregularly shaped, non-septate hyphae with right-angle branching; the fungi are often seen invading through tissue planes and blood vessels. Cultures are necessary to identify the fungal species and to perform antifungal susceptibility studies.

Since the mid-1970s, the prognosis of mucormycosis has improved markedly $[1,2]$. Therapy is based on early surgical debridement, amphotericin B administration, and stabilization of any underlying disease process $[2,20]$. If surgical debridement or correction of the underlying disease process cannot be accomplished, the response to amphotericin $\mathrm{B}$ alone is poor. The Mucorales are modestly susceptible to amphotericin $\mathrm{B}$, although in many instances it appears that in vitro susceptibility testing has not correlated well with the response of the patient to treatment with amphotericin $B[20]$. Newer antifungal agents, such as imidazoles and triazoles, appear to have no role in the treatment of mucormycosis [40]. A patient with mucormycosis related to deferoxamine therapy should be able to be effectively treated, since the underlying risk factor can be corrected. However, the diagnosis must be made quickly for therapy to be effective.

The implications of the association between deferoxamine therapy and mucormycosis are evident. The indications for deferoxamine therapy should be carefully weighed against the potential risk of mucormycosis. If deferoxamine is chosen, high clinical suspicion should be maintained for mucormycosis, especially if the patient presents with the aforementioned signs and symptoms. Immediate biopsy examination of involved tissue is essential for diagnosis, and cessation of deferoxamine, as well as aggressive surgical and antifungal therapy, is mandatory for survival.

\section{REFERENCES}

1. Marchevsky AM, Bottone EJ, Geller SA, Giger DK: The changing spectrum of disease, etiology, and diagnosis of mucormycosis. Hum Pathol 1980; 11: 457464.

2. Parfrey NA: Improved diagnosis and prognosis of mucormycosis. Medicine (Baitimore) 1986; 65: 113-123.

3. Virmani $\mathrm{R}$, Connor $\mathrm{DH}, \mathrm{McAllister} \mathrm{HA}$ : Cardiac mucormycosis. A report of five patients and review of 14 previously reported cases. Am J Clin Pathol 1982; 78: 42-47.

4. Brennan RO, Crain BJ, Proctor AM, Durack DT: Cunninghamella: a newly recog- nized cause of rhinocerebral mucormycosis. Am J Clin Pathol 1983; 80: 98-102. 5. Sands JM, Macher AM, Ley TJ, Neinhuis AW: Disseminated infection caused by Cunninghamella bertholletiae in a patient with beta-thalassemia. Ann Intern Med 1985 ; 102: 59-63.

6. Iqbal SM, Scheer RL: Myocardial mucormycosis with emboli in a hemodialysis patient. Am J Kidney Dis 1986; 8: 455-458.

7. Goodill JJ, Abuelo JG: Mucormycosis, a new risk of deferoxamine therapy in dialysis patients with aluminum or iron overload (letter)? N Engl J Med 1987; 317: 54.

8. Eiser AR, Slifkin RF, Neff MS: Intestinal mucormycosis in hemodialysis patients following deferoxamine. Am J Kidney Dis 1987; 10: 71-73.

9. Veis JH, Contiguglia R, Klein M, Mishell J, Alfrey AC, Shapiro JL: Mucormycosis in deferoxamine-treated patients on dialysis (letter). Ann Intern Med 1987; 107: 258. 10. Segal R, Zoller KA, Sherrard DJ, Coburn JW: Mucormycosis: a life-threatening complication of deferoxamine therapy in long-term dialysis patients (abstr). Kidney Int 1988; 33: 238.

11. Windus DW, Stokes TJ, Julian BA, Fenves AZ: Fatal rhizopus infections in hemodialysis patients receiving deferoxamine. Ann Intern Med 1987; 107: 678-680.

12. Sombolos K, Kalekou H, Barboutis K, Tzarou V: Fatal phycomycosis in a hemodialyzed patient receiving deferoxamine. Nephron 1988; 49: 169-170.

13. Johnson EV, Kline LB, Julian BA, Garcia JH: Bilateral cavernous sinus thrombosis due to mucormycosis. Arch Ophthalmol 1988; 106: 1089-1092.

14. Rex JH, Ginsberg AM, Fries LF, Pass HI, Kwon-Chung KJ: Cunninghamella bertholletiae associated with deferoxamine therapy. Rev Infect Dis 1988; 10: 1187-1194.

15. Boelaert JR, van Roost GF, Vergauwe PL, Verbanck JJ, de Vroey C, Segaert MF: The role of desferrioxamine in dialysis-associated mucormycosis: report of three cases and review of the literature. Clin Nephrol 1988; 29: 261-266.

16. Sane A, Manzi S, Perfect J, Herzberg AJ, Moor JO: Deferoxamine treatment is a risk factor for zygomycete infection. J Infect Dis 1989; 159: 151-152.

17. Gluskin M, Solomon MP, Gold B, Corrado JL, Berger J: Mucormycotic slough of nasal floor and palate in the anephric patient. J Am Dent Assoc 1979; 98: 224-227.

18. Rippon JW: Zygomycosis. In: Medical mycology. The pathogenic fungi and the pathogenic actinomycetes. Philadelphia: WB Saunders, 1988; 681-713.

19. Vainrub B, Macareno A, Mandel S, Musher DM: Wound zygomycosis (mucormycosis) in otherwise healthy adults. Am J Med 1988; 84: 546-548.

20. Lehrer RI, Howard DH, Sypherd PS, Edwards JE, Segal GP, Winston DJ: Mucormycosis. Ann Intern Med 1980; 93: 93-108.

21. Waldorf AR, Ruderman N, Diamond RD: Specific susceptibility to mucormycosis in murine diabetes and bronchoalveolar macrophage defense against Rhizopus. J Clin Invest 1984; 74: 150-160.

22. Diamond RD, Clark RA: Damage to Aspergillus fumigatus and Rhizopus oryzae hyphae by oxidative and nonoxidative microbiocidal products of human neutrophils in vitro. Infect Immun 1982; 38: 487-495.

23. Diamond RD, Hauderschild CC, Erickson NF: Monocyte-mediated damage to Rhizopus oryzae hyphae in vitro. Infect Immun 1982; 38: 292-297.

24. Meyer RD, Rosen P, Armstrong D: Phycomycosis compficating leukemia and lymphoma. Ann Intern Med 1972; 77: 871-879.

25. Thornton GF: Infections and diabetes. Med Clin North Am 1971; 55: 931-938. 26. Perillie PE, Nolan JP, Finch SC: Studies of the resistance to infection in diabetes mellitus: local exudative cellular response. J Lab Clin Med 1962; 59: 1008-1015. 27. Bauer H, Flanagan JF, Sheldon WH: The effects of metabolic alterations on experimental Rhizopus oryzae (mucormycosis) infection. Yale J Biol Med 1956; 29: $23-32$.

28. Artis WM, Fountain JA, Delcher HK, Jones HE: A mechanism of susceptibility to mucormycosis in diabetic ketoacidosis: transferrin and iron availability. Diabetes 1982; 31: 1109-1114.

29. Bullen JJ: The significance of iron in infection. Rev Infect Dis 1981; 3: 11271138 .

30. Payne SM: Iron and virulence in the family Enterobacteriaceae. CRC Crit Rev Microbiol 1988; 16: 81-111.

31. Mossey RT, Sondheimer J: Listerosis in patients with long-term hemodialysis and transfusional iron overload. Am J Med 1985; 79: 397-399.

32. Boelaert JR, von Landuyt HW, Valcke YJ, et al: The role of iron overload in Yersinia enterocolitica and Yersinia pseudotuberculosis bacteremia in hemodialysis patients. J Infect Dis 1987; 156: 384-387.

33. Weinberg ED: Iron and infections. Microbiol Rev 1978; 42; 45-66.

34. Robins-Browne RM, Prpic JK: Effects of iron and desferrioxamine on infections with Yersinia enterocolitica. Infect Immun 1985; 47: 774-779.

35. Wright AC, Simpson LM, Oliver JD: Role of iron in the pathogenesis of Vibrio vuinificus infections. Infect Immun 1981; 34: 503-507.

36. Seifert A, von Herrath D, Schaefer K: Iron overload, but not treatment with desferrioxamine favors the development of septicemia in patients on maintenance hemodialysis. O J Med 1987; 248: 1015-1024.

37. Gallant $T$, Freedman WH, Vellend $H$, Francombe WH: Yersinia sepsis in patients with iron overload treated with deferoxamine (letter). N Engl J Med 1986; 314: 1643.

38. Holzberg M Artis WM: Hydroxamate siderophore production by opportunisitic and systemic fungal pathogens. Infect Immun 1983; 40: 1134-1139.

39. Artis WM, Patrusky E, Rastinejad F, Duncan RL: Fungistatic mechanism of human transferrin for Rhizopus oryzae and Trichophyton mentagrophytes: alternative to simple iron deprivation. Infect Immun 1983; 41: 1269-1278.

40. Saag MS, Dismukes WE: Azole antifungal agents: emphasis on new triazoles. Antimicrob Agents Chemother 1988; 32: 1-8. 